\title{
YESUS SEBAGAI HAMBA \\ Kajian Kristologi Dan Relevansinya Pada Pelayan Gereja \\ Di Jemaat GPM Nehemia Sektor Petra
}

\section{Marlen Tineke Alakaman}

\begin{abstract}
The concept of Jesus as a servant of Jesus Christology other coloring concept in New Testament theology. In the concept of 'slave', Jesus shows a good example in serving a lot of people, where Jesus was aware of himself as the Son of God, He knows that he has the power, but He willingly emptied Himself and became equal with men, serving faithfully and obedient. In fact it demonstrated his obedience through sacrifice and took the decision to turn himself crucified for many people. Being a servant who lead and become a leader who is servile, that's what Jesus did. Thus, according to the reality of Jesus' servant leadership becomes interesting, when seen and relevanced on all of church serving or leaders of the community as that in persona Christi in the world church services as institutions serving the community of God's, or in theological terms is referred to as a church. In particular according to the author, this concept becomes interesting if the concept of leadership that was carried by Jesus is seen in the motion dynamics of the clergy congregation GPM Nehemiah Petra sector.
\end{abstract}

Keywords : Christology, the servant, the leader, the sacrifice, the Gospel of the Kingdom of God

\begin{abstract}
Abstrak
Konsep Yesus sebagai hamba adalah sebuah konsep Kristologi yang mewarnai konsep Kristologi Yesus lainnya dalam teologi Perjanjian Baru. Dalam konsep ini Yesus menunjukkan sebuah teladan yang baik dalam melayani banyak orang dimana, menyadari dirinya sebagai Anak Allah dan tahu benar bahwa Ia memiliki kekuasaan tetapi Ia rela mengosongkan diri-Nya dan menjadi sama dengan manusia melayani dengan setia dan taat bahkan ketaatan itu ditunjukkan-Nya lewat pengorbanan dan mengambil keputusan untuk meyerahkan diri-Nya disalibkan demi banyak orang. Menjadi seorang hamba yang memimpin dan menjadi seorang pemimpin yang menghamba, itulah yang dilakukan Yesus.Dengan demikian, realita ini menjadi menarik jika dilihat dan direlevansikan pada semua pelayan atau pun pemimpin umat yang melayani dan mewartakan Injil Kerajaan Allah, khusunya pelayan gereja sektor Petra Jemaat GPM Nehemia.
\end{abstract}

Kata Kunci : Kristologi, hamba, pemimpin, pengorbanan, Injil Kerajaan Allah 


\section{PENDAHULUAN}

\section{Latar belakang masalah}

Penelitian tentang siapakah Yesus Kristus, mempunyai istilah yang khusus dalam bahasa teologi Kristen, yaitu 'Kristologi'. ${ }^{1}$ Sebagaimana pada umumya, begitu pula dalam istilah Kristologi, akhirnya kata logi berarti ilmu (pengetahuan), oleh karena itu Kristologi artinya adalah ilmu pengetahuan tentang Kristus. Nico Syukur ${ }^{2}$ mengatakan bahwa, nama "Yesus Kristus", hanya bagian pertamanya, yakni "yesus", yang merupakan nama diri, sedangkan "kristus" bukanlah nama diri melainkan gelar yang menunjukkan fungsi dan peranan Yesus itu dalam sejarah penyelamatan. Yesus dalam realitas hidupnya, diberikan berbagai macam gelar yang memiliki arti dan makna tertentu bagi komunitas dari sang pemberi nama itu. Tokoh ini dikenal, dimengerti dan dipahami dalam realitas sekelompok orang yang hidup pada zamannya yang dikenal secara baik. Ada beberapa gelar yang diberikan kepada Yesus, yaitu: Yesus sebagai manusia, Yesus sebagai Tuhan, Yesus sebagai Mesias, Yesus sebagai Anak Allah, Yesus sebagai Nabi, dan lain-lain termasuk di dalamnya Yesus sebagai Hamba.

Citra Yesus sebagai hamba merupakan salah satu model kepemimpinan yang diperkenalkan kepada semua orang yang dalam realita sebagai pemimpin umumnya dan sebagai pemimpin kristen pada khususnya. Sebab dalam kepemimpinan bukanlah sebuah lukisan secara fisik orang itu yang dilihat semata, melainkan citra dirinya yang mesti menjadi perhatian, karena hal itulah yang menunjukkan dirinya adalah perpanjangan tangan Allah di dunia.Dalam realita pelayanan-Nya, Yesus menampakkan ciri seorang pemimpin yang tegas dan keras, khususnya dalam menghadapi para pemimpin Yahudi lainnya.Yang berikut juga ialah, nampak benar ketaatan dan keberanian Yesus sebagai hamba. Sebagai hamba, Yesus menjalani pilihan Allah, dan Ia tidak mundur darinya. Memang membutuhkan keberanian besar menghadapi resiko fatal dan situasi sulit yang lama, dibanding dengan tindakan kepahlawanan dalam situasi darurat. Yesus memiliki ketaatan yang hebat, kendati melihat akibat yang berat dan panjang itu. 
Realita hidup Yesus dan citra kepemimpinan-Nya yang telah diuraikan di atas, mestinya juga menjadi bagian dari kehidupan dan panggilan seorang Pelayan Gereja.Dapat dijelaskan bahwa, Pelayan Gereja juga bagian dari panggilan seseorang untuk melayani Kristus.Namun realita yang terjadi secara umum dalam berbagai gereja adalah yang selalu memahami bahwa para Pendeta, Penatua atau Majelis dan pengurus-pengurus wadah pelayanan dalam jemaat (Koordinator dan pengurus wadah pelayanan laki-laki, perempuan, angkatan muda, pengasuh dan lainya) adalah jabatan dari manusia itu, sehingga manusia itu merasa jabatan yang dipegang itu dipakai Allah.

Sering sekali dipahami bahwa Pelayan Gereja adalah sebuah jabatan sehingga Pelayan itu harus disanjung dan dipuji dalam kehidupan.Sebaliknya juga terjadi, para Pelayan itu juga merasa mempunyai kuasa dan kepemimpinan yang otoriter.Hal ini juga menjadi bagian dari pemahaman warga Gereja jemaat GPM Nehemia sektor Petra. Melayani anggota jemaat hanya karena suka dan tidak suka, melayani tidak dengan kerelaan dan kasih, suka memilih-milih anggota jemaat mana yang harus dilayani dan anggota jemaat mana yang nanti saja dari belakang kalau ada waktu, melayani hanya kepada anggota jemaat yang sering ke ibadah atau rajin masuk ibadah padahal anggota jemaat tersebut sudah terdaftar sebagai anggota unit atau sektor dimana ia berdiam atau tinggal, ada anggota jemaat yang mengeluh citra Pelayan Gereja, bahkan mempergunakan kuasa sebagai Pelayan sehingga seenaknya memerintah atas kepentingan diri tanpa melihat juga rekan kerjanya atau sesama Pelayan.

\section{KERANGKA TEORI}

\section{Yesus sebagai Hamba: Sebuah Landasan Teoritis}

Dalam konsep Kristologi, dapat saya katakan bahwa mesti kita membedakan antara hamba dan budak. Dalam hubungan antara Allah dan manusia, lebih condong kita pakai kata hamba. Tidak disangkali bahwa Alkitab versi Indonesia Terjemahan Baru, menuliskan 'hamba' lebih banyak daripada 'budak'. Didalam Perjanjian Baru, kata 'hamba' muncul didalam 159 ayat, 
sedangkan kata 'budak' hanya muncul didalam 4 ayat (1Kor.12:13, Kol.3:11, Why.6:15; 18:13). Akan tetapi sebagaimana ke-159 ayat yang menuliskan 'hamba', kata 'budak' - kecuali Why.18:13 - semuanya diterjemahkan dari kata $\delta$ oṽ $\lambda \mathrm{o} \varsigma=$ 'doulos's

Gelar "Hamba Allah" merupakan gelar yang memberi warna bagi gelargelar Yesus yang lain. Gelar ini mempunyai sejarah yang amat berharga dan besar. Dalam PL gelar ini diberikan kepada orang-orang yang pantas dibanggakan. Gelar itu memang mewarnai tokoh-tokoh puncak sejarah Israel, dan mereka itu adalah pelaku-pelaku penting dalam sejarah penyelamatan Allah.

Abraham adalah hamba Allah (Mzm 104: 42). Musa, si penyelamat, pemimpin agung, organisator ulung, penegak hukum yang amat keramat juga disebut Hamba Allah (Kel 14: 32; Bil 12:17; Yoh 1:1.15; 24:6). Yosua yang mewarisi kepemimpinan Musa mendapatkan gelar demikian (Yos 24:9; Hk 2:8). Elia, nabi agung juga dijuluki hamba Yahwe (2 Raj 10: 10). Gelar ini tidak hanya berlaku bagi orang perseorangan, melainkan juga bagi seluruh bangsa. Peranan umat itu dalam sejarah keselamatan begitu penting, sehingga Israel disebut hamba Allah (Yes 41: 8-10; 44:21; 48:20; 49:3). ${ }^{4}$

Di antara bangsa-bangsa lain, ciri khas Israel ialah "hamba Allah". Oleh karena itu gelar hamba Allah punya sejarah panjang, dan berjalan dalam pergumulan rohani Israel. Inilah sebabnya, gelar ini juga amat sesuai dengan perjuangan Yesus. Darmawijaya (1987), mengemukakan ada beberapa ciri yang bermakna besar bila gelar itu dikenakkan kepada Yesus.

a) Menyebut Yesus hamba Allah berarti menghubungkannya dengan tokoh-tokoh sejarah Israel, yang menyumbang perkembangan sejarah tersebut. Misalnya Musa, bahwa lewat tokoh inilah umat Allah dibebaskan dari perbudakan. Demikian juga Yesus, hamba Allah, manusia dibebaskan dan diselamatkan dari kuasa jahat.

b) Menyebut Yesus hamba Allah berarti menghubungkan-Nya dengan nabi-nabi yang menjadi pembawa suara Allah kepada manusia. Lewat mulut nabi Allah menyatakan kehendak, keinginan-Nya bagi manusia. 
Lewat Yesus Kristus sang nabi, terang dan kebenaran sabda-Nya disampaikan kepada manusia.

c) Gelar itu sesuai sekali dengan ciri hidup Yesus yang taat kepada Allah. Santapan-Nya adalah sabda tersebut (Yoh 4:34). Ia ada di dunia untuk melakukan sabda itu (Yoh 6:38). Ciri khas Hamba Allah adalah ketaatan. Dalam diri Yesus ketaatan itu sempurna.

d) Menyebut Yesus hamba Allah berarti bahwa di dalam Dia sejarah dan nasib Israel mendapatkan pemenuhan dan penyempurnaan. Karena hamba Allah inilah, maka bangsa itu berkembang dalam arah yang dikehendaki Allah. Gelar hamba Allah memang merupakan gelar yang erat hubungannya dengan seluruh sejarah Israel sebagai bangsa terpilih. $^{5}$

\section{Gereja sebagai lembaga yang memerintah}

Dalam konteksnya sebagai persekutuan orang-orang percaya tentunya harus ada pengaturan yang lebih baik di tengah dunia ini. Harus ada pengorganisasian terhadap gereja. Dalam hal ini diperlukan suatu kelembagaan dalam gereja supaya lebih terarah dalam mencapai misi gereja itu sendiri.

Menurut Berkhof bahwa ada para pejabat gereja yang mengelolanya yang kita sebut sebagai jabatan gereja, diantaranya: ${ }^{6}$

1. Pejabat luar biasa, terdiri atas tiga jabatan umum yang ditemukan dalam kesaksian Alkitab yaitu:

a. Rasul, adalah jabatan yang diberikan hanya kepada duabelas murid Yesus dan kepada Paulus. Tugasnya adalah untuk meletakkan dasar berdirinya gereja disegala abad.

b. Nabi, adalah mereka yang berbicara dibawah suatu inspirasi khusus, untuk bernubuat menyampaikan pesan-pesan Allah kepada umat.

c. Pemberita Injil, mereka berkhotbah, membaptis, tetapi juga mengangkat para pejabat gereja.

2. Pejabat biasa, mereka adalah: 
a. Tua-tua, adalah orang-orang yang dituakan dan kemudian juga disebut sebagai "penilik". Mereka adalah pelindung dan penjaga umat sebagai satu keluarga Allah.

b. Guru-guru, adalah orang-orang yang setia dan mengajar orang lain.

c. Diaken, dalam pengertian umum untuk pelayanan, yang semula dipekerjakan dan melayani secara eksklusif sepanjang waktu. Untuk menunjuk mereka yang terikat pada tugas untuk menyatakan belas kasih dan kebaikan, juga bahwa mereka diberi tugas untuk membagi-bagi pemberian yang telah diterima dari pelayanan agape atau kasih.

Dengan demikian, gereja sebagai sebuah lembaga mesti menyadari bahwa yang menjadi kepala atasnya adalah Krsitus, Kristus yang memerintah dan pelayan gereja adalah mereka yang terpanggil dalam sebuah kesadaran yang terikat pada suatu tugas khusus dan panggilan ini dilaksakan tanpa kenal batas waktu dalam artian terus-menerus. Oleh karenanya, segala sesuatu yang berkaitan dengan pelayan gereja dan pelayanannya mutlak mengikut jejak Kristus.

\section{METODE PENELITIAN}

\section{Tipe Penelitian}

Tipe penelitian yang digunakan di sini adalah penelitian diskriptif dengan menggunakan metode kualitatif.Tipe ini bertujuan untuk menggambarkan dan menjelaskan semua fenomena yang terdapat di dalam masalah yang diteliti meliputi pengumpulan data dan penyusunan data serta interpretasi dan analisa tentang arti data itu. ${ }^{7}$

\section{Lokasi Penelitian}

Berdasarkan judul di atas maka lokasi penelitian berada di sektor Petra jemaat GPM Nehemia Klasis Pulau Ambon. 


\section{Sumber data dan teknik pengumpulan data}

Teknik pengumpulan data merupakan langkah yang paling strategis dalam penelitian ini, karena mendapatkan data adalah tujuan utama. Data yang dikumpulkan dalam penelitian ini didapat dari data primer dan data sekunder. Data primer dikumpulkan lewat pengamatan atau analisa langsung di lapangan, wawancara langsung dengan pendekatan dan pemilihan objek penelitian dilakukan.Sedangkan data sekunder didapat dari instansi terkait serta dokumen-dokumen dan buku-buku sebagai rujukan pustaka.

\section{Teknik Analisa Data}

Data-data yang berhasil dihimpun dianalisa secara kualitatif.

\section{PEMBAHASAN}

\section{- Yesus sebagai Hamba}

Gelar "Hamba Allah" merupakan gelar yang memberi warna bagi gelargelar Yesus yang lain. Gelar ini mempunyai sejarah yang amat berharga dan besar. Dalam PL gelar ini diberikan kepada orang-orang yang pantas dibanggakan. Gelar itu memang mewarnai tokoh-tokoh puncak sejarah Israel, dan mereka itu adalah pelaku-pelaku penting dalam sejarah penyelamatan Allah.

Pengertian kata "hamba" dalam Kamus Besar Bahasa Indonesia, adalah seorang abdi atau orang yang merendahkan diri atau menyembah kepada tuannya. $^{8}$ Artinya bahwa dalam kondisi atau kehidupan sosial ada hubungan atau kedudukan di masyarakat, ada yang lebih tinggi dan ada yang lebih rendah. Yang lebih rendah itu salah satunya mereka yang juga memberi dirinya mengabdi kepada orang yang punya kedudukan tinggi.

Hal lain juga ialah bahwa, seseorang dikatakan "hamba" adalah orang suruhan yang mempunyai tugas atau tanggung jawab untuk dapat melakukan sesuatu yang diperintahkan dan dipercayakan untuk melakukan tugas itu. Dan dalam melakukan tugas itu, orang tersebut atau yang disebut "hamba" itu, dapat melakukan tugasnya dengan tanggung jawab dan selalu dituntu untuk 
taat dan setia. Jadi sebenarnya, dari pengertian di atas menegaskan bahwa, yang disebut sebagai "hamba" adalah orang suruhan atau bawahan yang dianggap lemah dan selalu tunduk dan taat serta setia kepada perintah tuan atau mereka yang punya kuasa atau yang berkuasa atas diri orang itu.

Kata "hamba" bukan hanya pada dunia sekuler saja tetapi dalam dunia Alkitabiah kata ini juga sering dipakai oleh penulis-penulis kitab. Pengertian kata "hamba" dalam dunia sekuler dengan tradisi Perjanjian Lama hampir sama yakni keduanya menekankan kepada "orang suruhan". Namun perjanjian lama memiliki ciri khusus, sehubungan dengan orang suruhan tersebut. Pemakaian kata "hamba" dalam Perjanjian lama berhubungan dengan panggilan Allah kepada orang-orang yang dipercayakan-Nya. Pemakaian kata 'hamba" yang berhubungan dengan panggilan Allahini kepada pribadi-pribadi yang dipilih secara khusus, banyak ditemukan dalam kitab Nabi-nabi Besar dan Nabi-nabi Kecil. Dan orang yang mendapat panggilan khusus dari Allah biasanya disebut "hamba Allah" atau "Nabi". 9

Gambaran Yesus sebagai hamba Allah mencapai puncaknya dalam gambaran hamba yang menderita. Dan hal ini menurut Guthrie (2009), hamba yang menderita dengan jelas memainkan peranan yang penting dalam pengertian kita tentang karya Kristus. $^{10}$ Satu-satunya gambaran yang memberikan dasar pada pemahaman ini adalah citra hamba Allah. Artinya bahwa, Yesus mengambil resiko / salib. Salib itu bukan hal yang dipaksakan pada-Nya tanpa Ia bisa memilih. Yesus bukan korban manusia maupun situasi. Sejak awal Yesus melihat resiko perjuangan-Nya memuat kemuliaan, tragedi dan kemenangan.

Yang berikut juga ialah, dalam resiko itu nampak benar ketaatan dan keberanian Yesus sebagai hamba. Sebagai hamba, Yesus menjalani pilihan Allah, dan Ia tidak mundur dari-Nya. Memang membutuhkan keberanian besar menghadapi resiko fatal dan situasi sulit yang lama, dibanding dengan tindakan kepahlawanan dalam situasi darurat. Yesus memiliki ketaatan yang hebat, kendati melihat akibat yang berat dan panjang itu. Yesus mengesampingkan 
kemuliaan, kedudukan segala hak sorgawi, dan penggunaan sifat-sifat ialahiNya (bnd. Yoh 14:4, Luk.22:27, Mat.20:28).

- Relevansi konsep Yesus sebagai Hamba pada pelayan Gereja di Jemaat GPM Nehemia Sektor Petra

\section{$>$ Pelayan Gereja yang Melayani}

Pemaknaan nilai-nilai dari konsep Yesus sebagai hamba dianggap sangatlah penting dalam upaya melakukan panggilan dan tanggung jawab sebagai seorang pelayan dalam realita pelayanan umat. Dalam situasi dan realita yang telah dipaparkan pada bab-bab sebelumnya, konsep Yesus sebagai hamba secara kritis dan terbuka mesti menjadi bagian yang tidak terlepaskan atau harga mati seorang Pelayan Gereja.

Konsep melayani adalah konsep yang mewarnai pribadi hamba Allah. Hal ini berakar dari pengertian kata "Hamba" yang dalam Perjanjian Baru,

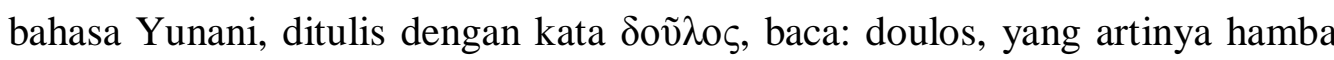
dan tugasnya sebagai diakonos, yang berarti pelayan sehingga dapat dimengerti bahwa yang namanya "hamba" atau doulos adalah orang yang melayani atau diakeneo. ${ }^{11}$ Konsep ini diperkuat dengan apa yang Yesus ucapkan ketika permintaan Yakobus dan Yohanes untuk duduk dalam kemuliaan Allah kelak yang seorang disebelah kanan dan yang seorang lagi di sebelah kiri. Sebuah permintaan yang sulit dan tidak dapat dipenuhi begitu saja. Yesus dengan tegas menjawab: Tetapi barang siapa yang ingin menjadi besar diantara kamu, hendaklah ia menjadi pelayanmu, dan barangsiapa ingin menjadi terkemuka di antara kamu, hendaklah ia menjadi hamba untuk semuanya (Baca, Mark. $10: 35-45)$.

Sebenarnya, yang Yesus tegaskan ini menunjukkan bahwa Yesus menginginkan dan memberikan contoh kepada para murid sebagai pengikutNya untuk selalu hidup dalam kerendahan untuk melayani orang lain. Oleh karena itu, untuk melakukan semuanya mesti ada aksi yang ditunjukkan yakni perbuatan nyata yang dalam hidup sesehari bukan hanya sebuah perkataan 
yang keluar dari mulut masing-masing orang. Sebab hal ini juga yang dilakukan Yesus ketika Ia berada di dunia.

Pelayanan yang Yesus lakukan adalah melayani tanpa pandang bulu, entah itu anak kecil, orang muda, dan orang tua, laki-laki atau perempuan. Ia bahkan menunjukkan perhatian yang mendalam kepada mereka yang benarbenar membutuhkan pelayanan dari-Nya yakni orang miskin dan kekurangan, orang-orang lemah dan tertindas, mereka yang termarginalkan dalam masyarakat secara sosial, sampai pada mereka yang kena sakit kusta yang dikucilkan dalam masyarakat bahkan dijauhkan dari pemukiman rakyat karena dianggap mendatangkan kutuk pun Yesus layani dengan tidak bersungut dan merasa najis dan kotor tangan-Nya. Bahkan mereka inilah yang Yesus prioritaskan dalam pelayanan-Nya untuk segera dilayani mendahului mereka yang lain.

Sering sekali seperti yang diceritakan dalam kitab-kitab Injil bahwa murid-murid Yesus sendiri bahkan pernah melarang orang-orang untuk tidak berbondong-bondong dan membuat Yesus kelelahan karena Yesus pun memerlukan istirahat, tetapi Yesus bahkan tidak pernah mengahalang-halangi orang banyak untuk datang mendapatkan pelayanan dari-Nya.

Yesus sendiri pun tidak pernah membiarkan orang-orang yang membutuhkan pelayanan-Nya, walaupun sebagai manusia juga Ia merasa kelelahan berjalan seharian melakukan pelayanan, namun patut dipelajari oleh pelayan gereja bahwa semua itu tidak membuat-Nya berhenti untuk tidak melayani. Hal ini sebenarnya menunjukkan bahwa Yesus sebagai manusia biasa yang penuh dengan keterbatasan benar-benar memaknai panggilan-Nya sebagai pelayan yang penuh kasih untuk melayani semua orang yang datang, juga menunjukkan bahwa Ia adalah sosok seorang hamba yang melayani dengan kasih yang tak terbatas, bahkan kasih itu ditunjukkan-Nya pada pengorbanan di salib.

Hal ini ditegaskan oleh pelayan gereja berdasarkan hasil wawancara dengan beberapa pelayan di sektor, mereka mengatakan bahwa: 
Kita sebagai pelayan kadang mau melayani karena suka, kalau ada maunya, karena melihat status orang yang dilayani. Terkadang katong sebagai pelayan seng menyadari dengan benar katong pung tugas. Kadang mau pi pelayanan musti tunggu suka do, yang berikut, kadang kala kalo ada seng suka orang katong seng pi melayani di dia rumah. ${ }^{12}$

Hal ini menunjukkan bahwa, pelayan mesti menyadari tugas dan panggilannya terhadap Tuhan dan juga terhadap manusia dengan meneladankan apa yang Yesus kerjakan ketika Ia juga melayani di dunia. Dengan demikian apa yang dilakukan Yesus kepada murid-murid dan juga kita yang terpanggil sebagai pelayan atau murid-murid, bahwa Yesus adalah Anak Allah yang Maha Tinggi dan mempunyai kuasa dan kesempurnaan Ilahi, namun dengan rela mau merendahkan diri untuk melayani sebagai seorang hamba yang setia dan taat.

Bahwa menjadi seorang pelayan gereja adalah mampu memaknai keterpanggilan sebagai seorang yang diutus, diurapi untuk melayani, yakni melayani sebagai seorang hamba yang tidak mementingkan diri sendiri, harus jadi teladan, bahkan mampu menyatu dengan umat, artinya bahwa dalam melakukan tugas pelayanan tidak ada jarak antara pelayan dan umat yang dilayani. ${ }^{13}$ Menjadi pelayan gereja juga harus belajar dan menumbuhkan sikap rendah diri, belajar dari Yesus walaupun sebagai manusia kita tidak akan mungkin sama seperti Yesus tapi sebenarnya kita dapat belajar menjadikan diri kita contoh yang Yesus lakukan dalam melayani orang banyak ketika Ia masih hidup. ${ }^{14}$ Sebagai pelayan gereja, mesti belajar dari apa yang Yesus buat, Yesus bahkan dapat membasuh kaki murid-murid-Nya yang menunjukkan bahwa Ia yang pada waktu itu punya kekuasaan dan sebagai pemimpin bagi muridmuridnya, tapi sanggup melakukan hal yang paling rendah dan sangat menjijikan. Hal itu, mesti menjadi contoh yang harus dilakukan sebagai pelayan gereja, mau melayani dengan kesungguhan hati dan rendah diri. ${ }^{15}$

Hal ini menunjukkan bahwa Yesus benar-benar menjadikan diri-Nya seorang hamba yang melayani. Berdasarkan hasil wawancara di atas, hal ini pun diceritakan oleh penulis kitab Injil bahwa Yesus rela memberikan diri-Nya 
untuk menjadi pelayan bagi para murid dengan membasuh kaki mereka seperti yang diceritakan dalam Yohanes 13:4-5, bahwa: "lalu bangunlah Yesus menanggalkan jubah-Nya. Ia mengambil sehelai kain lenan dan mengikatnya pada pinggang-Nya, kemudian Ia menuangkan air kedalam sebuah basi, dan mulai membasuh kaki murid-murid-Nya lalu menyekanya dengan kain yang terikat pada pinggang-Nya itu. Ayat ini memberi penjelasan kepada kita dan juga pelayan gereja bahwa Yesus berinisiatif sendiri untuk melayani para murid.

Jika kita menyimak dengan baik rentetan cerita ini, maka kita akan menemukan beberapa hal yang menjadi catatan penting soal pelayanan. Kalimat membasuh kaki, kaki adalah salah satu anggota tubuh manusia yang paling bawah dan kotor karena berjalan dan melakukan aktifitas yang banyak mendapat debu dan kotoran. Jika debu itu tertinggal lama maka akan mendatangkan bau yang tidak enak. Kaki juga menunjukkan sesuatu yang paling bawah jika dilihat dari posisi atau kedudukannya.

Yang berikut ialah bahwa, proses dimana Yesus membasuh kaki para murid-Nya, Ia berhadapan dengan mereka seakan-akan Ia adalah seorang pelayan yang sedang berhadapan dengan tuannya.Ini menunjukkan bahwa dalam kerelaan dan kerendahan seorang hamba Yesus harus melakukannya. Sosok seorang pemimpin, seorang guru, seorang rabi dan tuan bagi para murid, namun adalah sesuatu yang menjadi contoh bagi pemimpin-pemimpin gereja yang lain bahwa melayani adalah ukuran atau standar yang hakiki sebagai pengikut dan pelayan yang mewartakan Injil Kerajaan Allah.

Ini menunjukkan bahwa, sebagai pelayan gereja yang telah memberi diri dengan kesungguhan hati untuk melayani umat, mesti mampu memaknai apa yang menjadi bagian dari tugas dan panggilannya dalam pelayanan yang dilakukan dalam sektor-sektor pelayanan dimana ia ditempatkan. Belajar dari Yesus yang melayani dengan merendahkan diri-Nya karena Ia tahu bahwa diluar kekuatan Ilahi-Nya Ia juga adalah manusia. Sebagai anak Allah, Yesus sendiri mau mengosongkan diri-Nya dan mengambil rupa seorang hamba dan 
menjadi sama seperti manusia, merendahkan diri-Nya dan taat sampai mati (baca Filipi 2:4-9).

Dalam peran-Nya sebagai hamba Allah, Yesus berkorban untuk melayani orang lain (manusia dalam keberdosaannya), pengorbanan dan penderitaan yang harus ditanggung-Nya mesti benar-benar dimaknai oleh kita semua yang terpanggil sebagai pelayan gereja. Melayani dengan kerendahan hati yang didasarkan pada kasih yang tulus mesti juga menjadi bagian yang terpisahkan dalam pelayanan pelayan gereja di sektor Petra jemaat Nehemia. Walaupun disadari sungguh bahwa tugas seorang pelayan adalah juga bagian dari panggilannya sebagai pelayan yang diberikan Tuhan, dan oleh karena itu pelayan gereja diharuskan untuk menjalankan tugas melayani dengan kerendahan diri dan kasih, bukan dengan kesombongan dan hanya sekedar menunaikan atau menjalankannya.

\section{$>$ Pelayan Gereja yang belajar dari kehambaan Yesus}

Yesus adalah pribadi kedua dari tritunggal, yang memiliki segala kuasa dan kemuliaan. Bahkan dalam kapasitas-Nya sebagai Allah, Ia telah ada di kekekalan masa lampau dan menjadi pencipta alam semesta beserta isinya. Namun tanpa mempertahankan diri-Nya sebagai Allah, Ia telah berinkarnasi sama seperti manusia. Dan dalam kemanusian-Nya Yesus hidup dalam segala keadaan dan keberadaan yang juga merasakan apa yang dirasakan oleh manusia biasa yakni: lapar, haus, mengantuk, lelah bahkan marah dan juga yang paling penting adalah Ia juga mengalami kematian sama seperti manusia lainnya. Tetapi daripada-Nya kita belajar memaknai keterpanggilan kita sebagai pelayan.

\section{Pelayan yang belajar dari teladan seorang pemimpin.}

kata pemimpin dalam bahasa Yunani diterjemahkan dari kata benda: hodegos yang artinya pemimpin, penuntun, pembimbing. Dalam bentuk kata kerja dipakai kata : Hodegein yang berarti memimpin, menuntun, memimbing. ${ }^{16}$ A.M. Manguhardjana (1990) mengatakan bahwa: Kata kerja 
memimpin, menuntun, membimbing, memiliki beberapa arti, antara lain: menunjukkan jalan terutama berjalan didepan, menuntun, membimbing, mengambil langkah awal, mempengaruhi orang dengan pandangan dan tindakan, memprakarsai, bertindak lebih dahulu, mempelopori, mengarahkan pikiran atau pendapat, menggerakkan orang lain dengan pengaruhnya, dan lainlain. $^{17}$

Kepemimpinan dewasa ini dapat dibedakan kedalam dua golongan yaitu golongan pertama kepemimpinan di wilayah sekuler dan kedua kepemimpinan di wilayah yang religius. Pemimpin sekuler yaitu mereka yang dipilih untuk memangku jabatan tertentu di bidang pemerintahan atau perusahaan.Sedangkan pemimpin religius yaitu mereka yang memimpin dibidang keagaamaan. Misalnya: Nabi, Rasul, Pendeta, Penatua, Diaken dan Penilik dan lain sebagainya.Dengan demikian, Jika dilihat dari pembagian wilayah kepemimpinan diatas dan yang telah diuraikan sebelumnya bahwa, Yesus dapat kita golongkan pada posisi pemimpin wilayah religius yaitu Rabi.

Pemimpin Kristen berarti pemimpin yang mengenal Allah secara pribadi dalam Makna pemimpin dalam konsepsi Alkitab, bukan berarti seseorang disebut pemimpin rohani (Kristen) karena ia Kristen dan memimpin secara kristiani. Pemimpin Kristen adalah pribadi yang memiliki perpaduan antara sifat-sifat alamiah dan sifat-sifat spiritualitas Kristen. Sifat-sifat alamiahnya mencapai efektivitas yang benar dan tertinggi karena dipakai untuk melayani dan memuliakan Allah. Sedangkan sifat-sifat spiritualitas kristianinya menyebabkan ia sanggup mempengaruhi orang-orang yang dipimpinnya untuk menaati dan memuliakan Allah. Sebab daya pengaruhnya bukan dari kepribadian dan ketrampilan dirinya sendiri, tetapi dari kepribadian yang diperbaharui Roh Kudus dan karunia yang dianugerahkan Roh Kudus. ${ }^{18}$

Dengan demikian, maka hal di atas menunjukkan bahwa pemimpin Kristen (religius) berbeda dengan pemimpin alamiah (sekuler) dalam beberapa hal.Pemimpin rohani mengenal Allah,mencari kehendak Allah, menaati kehendak Allah, bergantung pada Allah, mengasihi Allah dan manusia, dan akhirnya memuliakan Allah. Sedangkan pemimpin alamiah hanya mengenal 
manusia, membuat keputusan sendiri atau organisasi, berusaha mencapai sasaran pribadi atau organisasi, bersandar pada cara-cara sendiri,bergantung pada kuasa dan ketrampilan diri sendiri, mengutamakan hasil kerja dan cenderung mengabaikan manusia. Hal ini yang juga menjadi bagian dari pribadi Yesus sebagai pemimpin.

Berdasarkan hasil wawancara dengan beberapa pelayan gereja yang mengemukakan soal kepemimpinannya sepanjang menjadi pelayan bahwa:

Pelayan juga adalah seorang pemimpin karena dia adalah sosok yang bertanggung jawab mengarahkan serta memberdayakan anggota jemaatnya yang ia pimpin. ${ }^{19}$ Pelayan atau pemimpin gereja sekarang ini belum mampu menjadi seperti yang Yesus jalankan.Ia belum memiliki hati sebagai hamba, ia belum mencari kehendak Allah. Dengan kekuasaan yang ia punya juga sebagai pemimpin gereja bisa meracuni pikiran orang lain. Belum juga mencari dan melihat hak orang lain. ${ }^{20}$

\section{Pelayan yang memberi teladan dalam kata maupun sikap hidup}

Menjadi pelayan yang memberi teladan dalam kata maupun diwujudkan dalam sikap hidup mungkin merupakan suatu hal yang terlihat sangat sederhana dan praktis di dengar namun, ini juga sebenarnya yang ditunjukkan Yesus jika kita belajar dari cerita alkitab yakni dalam proses pengajaran-pengajaran Yesus yang diceritakan dalam kitab Injil bahwa Yesus tidak hanya mengajar atau berkata-kata tetapi Ia juga melakukan apa yang dikatakan-Nya. Itu sebabnya, hal memberi teladan adalah bukan soal yang dikatakan saja sebagai seorang pelayan tetapi juga apa yang dikatakannya haruslah juga dilakukannya. Hal ini menunjukkan bahwa sikap sangatlah memainkan peranan penting bagi seorang pelayan Kristen, supaya setiap perkataan yang diucapkan tidaklah sia-sia melainkan mendatangkan berkat bagi diri pelayan itu sendiri maupun orang lain, bisa menghibur bahkan menguatkan orang lain.

Berdasarkan hasil wawancara dengan beberap pelayan, mereka mengatakan bahwa: 
Sikap sangat penting dalam peran seorang pelayan, karena sikap merupakan perbuatan nyata atas apa atau siapa dia (yaitu seorang pelayan Tuhan), apa yang dia tahu tentang Tuhan, apa yang dia tahu ucapkan tentang Tuhan di tempat-tempat ibadah. ${ }^{21}$ Sikap seorang pelayan itu penting, ia harus jadi contoh, bilang sesuatu harus lakukan dalam pemberitaan, beri nasihat tapi penting juga keteladanan. ${ }^{22}$ Seorang pelayan tidak seharusnya menunjukkan sikap berkuasa atas orang lain. ${ }^{23}$

Oleh karenanya, sikap sangatlah penting bagi seorang pelayan yang melayani umat, bahwa ia harus menjadi contoh atau teladan bagi orang lain, tidak menunjukkan sikap berkuasa atas orang lain.Karena kekuasaan yang mutlak benar-benar merusak, walaupun boleh dikatakan bahwa seorang pemimpin atau sebuah kepemimpinan jika tidak memiliki kuasa bukanlah pemimpin ataupun kepemimpinan, hanyalah menjadi sebuah jabatan yang kosong.Belajarlah kita dari cerita Alkitab tentang godaan yang pertama kali dicatat dalam sejarah manusia berkenaan dengan pengendalian (Kej. 3:1-5).Hal ini disebabkan karena hasrat untuk mengendalikan mudah dipengaruhi oleh sifat dasar manusia yaitu kuasa.

Alan, juga mengatakan, ${ }^{24}$ Kata "rendah hati” berasal dari akar kata yang sama dengan "humus", yang artinya tanah yang gembur, subur, dan mengandung unsur-unsur yang sedang membusuk. Apabila manusia lama kita mati, dan dikombinasikan dengan Roh Allah, maka akan tercipta kondisi yang sehat. Kerendahan hati bagi jiwa ibarat pupuk kebun.Tunduk Kepada kuasa Allah dan pengendalian-Nya menuntut kedisiplinan dan kebulatan tekad. Pelayan harus mempelajari hal ini dengan serius, sama seperti pelari gawang yang berlatih agar dapat berlari dan melompat tanpa kehilangan keseimbangan. Bagi pemimpin atau seorang pelayan, tugas ini dua kali lebih sulit.Apabila kita merasa harus mengambil keputusan, menggunakan kekuasaan, dan menggunakan talenta-talenta pemberian Allah tanpa kehadiran kuasa Allah, kepemimpinanan dan pelayanan kita cenderung menjadi buruk. 
Kuasa dan berkuasa atas orang lain juga adalah bagian dari sisi kemanusiaan seorang pelayan gereja tetapi sebenarnya jika seorang pelayan gereja dengan sungguh berserah kepada Allah dan belajar dari apa yang Yesus lakukan yakni melayani dengan mencari kehendak Allah. Oleh karenanya sebagai seorang pelayan gereja mesti mengizinkan Allah memegang kendali pelayanan yang dilakukan.Pola pelayanan Yesus sebagai hamba mesti menjadi bagian yang tak lepas dari pelayanan yang dilakukan juga oleh pelayan gereja masa kini, menjadi teladan, dan minimal atau perlahan-lahan harus dilakukan.

\section{Pelayan gereja yang taat dan setia}

Kehambaan Yesus juga berhubungan dengan ketataan dan kesetiaan.Darmawijaya mengatakan, Gelar hamba itu sesuai sekali dengan ciri hidup Yesus yang taat kepada Allah.Santapan-Nya adalah sabda tersebut (Yoh 4:34).Ia ada di dunia untuk melakukan sabda itu (Yoh 6:38). Ciri khas Hamba Allah adalah ketaatan.Dalam diri Yesus ketaatan itu sempurna. ${ }^{25}$ Hal ini juga disaksikan dalam cerita alkitab bagi semua orang yang mengimani Yesus sebagai anak Allah yakni, ketika Ia berada di taman Getzemani berdoa sambil menanti saat terakhir hidup-Nya, ditangkap dan disalibkan. Yesus dalam sisi kemanusiaan-Nya masih sempat untuk berdoa dan meminta pengampunan tetapi yang menarik ialah, Ia berlutut dan berdoa, kata-Nya: "Ya Bapa-Ku, jikalau Engkau mau, ambilah cawan ini dari pada-Ku; tetapi bukanlah kehendak-Ku, melainkan kehendak-Mulah yang terjadi.” (Luk. 22:42).

Ayat ini sebenarnya mau menjelaskan kepada kita dan juga kepada pelayan gereja yang belajar dari ketaatan dan kesetiaan Yesus bahwa, Yesus mau penderitaan yang Ia alami berlalu dari pada-Nya. Secara manusia, cawan penderitaan tidak mau ia alami tetapi Yesus lebih memilih taat dan setia, serahkan semua pada Allah Bapa-Nya yang menentukan. Kepasrahan dan penyerahan segala keputusan penderitaan yang dialami Yesus kepada BapaNya adalah wujud nyata ketaatan dan kesetiaan seorang hamba Allah. 


\section{PENUTUP}

Konsep Kristologi Yesus sebagai hamba adalah konsep yang dibangun berdasarkan seluruh rangkaian kehidupan Yesus dan karya penyelamatan yang telah dikerjakannya semasa Ia hidup dan berkarya menjalankan misi Kerajaan Allah. Konsep kristologi Yesus sebagai hamba juga adalah konsep yang mewarnai kristologi yang lain dan menjadi suatu yang diimani oleh semua orang yang percaya pada-Nya. Dan belajar dari kristologi: penyebutan dan pemberian gelar dalam diri Yesus sebagai hamba, mencirikan seorang pelayan yang membedakan dengan pelayan-pelayan yang lain (non-religius). Konsep pelayan yang punya kekuasaan tetapi kekuasaan itu dipakai untuk melayani sebagaimana konsep hamba yang melayani.Hal ini yang juga mesti menjadi konsep bersama pelayan gereja dan semua pelayan yang terpanggil untuk melayani di ladang Tuhan khusunya pelayan gereja sektor Petra jemaat GPM Nehemia. Bahwa, sebagaimanaapa yang di lakukan dan ditunjukkan Yesus sebagai hamba; hamba yang melayani, itu juga yang harus menjadi bagian yang tidak terpisahkan dalam diri pelayan gereja sektor Petra jemaat GPM Nehemia. Pelayan gereja yang belajar dari Kehambaan Yesus yakni melayani. Melayani dengan kerendahan hati, tidak sombong, tidak menganggap diri berkuasa, tidak memandang suku dan ras, melayani dengan perkataan dan sikap yang menyenangkan dan membawa sukacita bagi diri dan sesama, bersikap positif, dan melayani dengan taat dan setia.

\section{Catatan akhir}

${ }^{1}$ Donald Guthrie. 2009, Teologi perjanjian Baru 1: Allah, Manusia, Kristus, Jakarta: BPK Gunung Mulia, h. 243

${ }^{2}$ Nico Syukur., 1987, KRISTOLOGI sebuah sketsa, Jogyakarta: Kanisius, h. 24

${ }^{3}$ Budak atau Hamba, http:// www.ask.com.Diunduh Februari 2012

${ }^{4}$ Darmawijaya, Gelar-gelar Yesus, ...h.103-104.

${ }^{5}$ Ibid, h.104-105

${ }^{6} \mathrm{H}$. Hadari Nawawi, Metode Penelitian Bidang Sosial, Yogyakarta: Gadja Mada University Press, 1983, h. 63.

${ }^{7}$ El Santoso dan Suprianto, Kamus Besar Bahasa Indonesia, Surabaya: TB Tangerang, 2003, h. 146 
${ }^{8}$ Ellison "Hamba" dalam Ensiklopedi Masa Kini, Jilid I: A-I, Jakarta: Yayasan Komunikasi Bina Kasih/OMF, h. 360

${ }^{9}$ Donald Guthrie,Teologi perjanjian Barui... h. 303

${ }^{10}$ Franscis Brown, Interlinear Yunani-Indonesia, Jakarta: Lembaga Alkitab Indonesia, 1998, h. 224.

${ }^{11}$ Hasil wawancara dengan Ibu C.F (koordinator unit 2), tanggal 13 september 2013, pukul 10.29 wit

${ }^{12}$ Hasil wawancara dengan Ibu P.H (koordinator unit 1), tanggal 27 September 2013, pukul 10.00 wit

${ }^{13}$ Hasil wawancara dengan Ibu Diaken P.N. (Majelis domisili seKtor), tanggal 14 September 2013, Pukul: 11.00 Wit.

${ }^{14}$ Hasil Wawancara dengan Ibu Penatua L.N (Ketua sektor), tanggal 20 September 2013, Pukul: 12.30 Wit

${ }^{15}$ Hasil wawancara dengan Bpk Diaken J.F. (Majelis domisili Sektor), Tanggal, 13 September 2013, Pukul: 10.15 Wit

${ }^{16}$ A.S Horby, Oxford Advanced Learner's Dictionary, ( Oxford: University Press, 1989 ), h. 708

${ }^{17}$ A.M. Manguhardjana, 1990, Kepemimpinan, Jogyakarta: Kanisius, h. 11

${ }^{18}$ Kepemimpinan Kristen, http://gkagloria.or.id/artikel, diakses Februari 2012

${ }^{19}$ Hasil wawancara dengan Bung B.P (ketua AMGPM Ranting Ebed), pada tanggal 28 September 2013, pukul 17.20 wit

${ }^{20}$ Hasil wawancara dengan Pdt. S.M (pendeta domoisili), tanggal 04 Agustus 2013, pukul 09.15 wit

${ }^{21}$ Hasil wawancara dengan F.L (Pengasuh Sektor), Tanggal 04-08-2013, Pukul: 13.00 wit

${ }^{22}$ Hasil wawancara dengan Diaken Ibu P.N (Majelis domisili).Tanggal 14-09-2013, Pukul 11.00 wit

${ }^{23}$ Hasil wawancara dengan Ibu S.S (Koordinator unit 2), Tanggal 13 September 2013, pukul 20.10 wit

${ }^{24}$ Alan E.Nelson, 2007, Spirituality \& Leadership,Bandung; Yayasan Kalam Hidup, h.141

${ }^{25}$ Alan E.Nelson, 2007, Spirituality \& Leadership,... h.141

\section{DAFTAR PUSTAKA}

Alan E.Nelson, 2007, Spirituality \& Leadership, Bandung; Yayasan Kalam Hidup

Berkhof Louis, 1997, Teologi Sistematika V (Doktrin Gereja), Surabaya, Momentum.

Brown, Franscis, Interlinear Yunani-Indonesia, Jakarta: Lembaga Alkitab Indonesia, 1998

Darmawijaya, St. 1987, Gelar-gelar Yesus, Yogyakarta: Kanisius

Guthrie Donald. 2009, Teologi perjanjian Baru 1: Allah, Manusia, Kristus, Jakarta: BPK Gunung Mulia.

Horby, A.S. 1987. Oxford advanced Learner's dictionary, Oxford: University Press

Ismail Andar. 2001, Selamat Mengikuti Dia, Jakarta: BPK Gunung Mulia

Manguhardjana, A.M. 1990, Kepemimpinan, Jogyakarta: Kanisius

Nelson, Alan E. 2007, Spirituality \& Leadership, Bandung: yayasan Kalam Hidup 
Syukur Nico, 1987, Kristologi Sebuah Sketsa, Yogyakarta: Kanisius.

Robert R. Boehlke. 2001. Siapakah Yesus Sebenarnya, Jakarta: BPK Gunung Mulia

Santoso El dan Suprianto. 2003. Kamus Besar Bahasa Indonesia, Surabaya: TB Tangerang

Ellison. Ensiklopedi Masa Kini, Jilid I: A-I, Jakarta: Yayasan Komunikasi Bina Kasih/OFM

Budak atau Hamba, http:// www.ask.com.

Yesus dalam Injil Lukas, http://www.google.co.

Kepemimpinan Kristen, http://gkagloria.or.id/artikel 